\title{
KAJIAN BIAYA GEDUNG BERTINGKAT MENGGUNAKAN DINDING BATU BATA MERAH DIBANDINGKAN DENGAN BATU BATA RINGAN
}

\author{
Singkop Lensius Sinaga ${ }^{1}$, Redmi Fronika Sihotang ${ }^{2}$, Bambang Winarno ${ }^{3}$ \\ ${ }^{1}$ Program Studi Manajemen Rekayasa Konstruksi Gedung, Politeknik Negeri Medan \\ Email: singkopsinaga@students.polmed.ac.id \\ ${ }^{2}$ Program Studi Manajemen Rekayasa Konstruksi Gedung, Politeknik Negeri Medan \\ ${ }^{3}$ Program Studi Manajemen Rekayasa Konstruksi Gedung, Politeknik Negeri Medan
}

\begin{abstract}
Abstrak. Berdasarkan Perencanaan Desain Berulang Pembangunan Rusun TA 2019 tentang Material dan Spesifikasi yang dikeluarkan PUPR, material dinding menggunakan batu bata ringan. Kajian ini bertujuan untuk menganalisis selisih biaya gedung bertingkat dengan material dinding batu bata ringan dibandingkan dengan batu bata merah. Studi dilakukan dengan beberapa variasi tingkat bangunan mulai dari 4 tingkat, 6 tingkat dan 8 tingkat dengan material dinding batu bata ringan dibandingkan dengan batu bata merah pada simulasi bangunan bertingkat di kota Medan. Langkah untuk mendapatkan selisih biaya bangunan : membuat data pemodelan struktur, pendimensian struktur, pembebanan struktur, analisa struktur, pendimensian pondasi dan perhitungan biaya. Hasil kajian dapat disimpulkan penggunaan material dinding : 1). Batu bata ringan lebih mahal dibandingkan dengan batu bata merah, terdapat selisih biaya Rp 201.368.199 atau persentase perbandingan $6,187 \%$ untuk tingkat 4 dan terdapat selisih biaya Rp 127.922.160 atau persentase perbandingan $2,471 \%$ untuk tingkat 6 , sedangkan untuk tingkat 8 batu bata ringan lebih murah dibandingkan dengan batu bata merah, terdapat selisih biaya Rp 26.023.766 atau persentase perbandingan $0,375 \%$. 2). Dinding batu bata ringan lebih murah dibandingkan dengan batu bata merah mulai tingkat 8 , sedangkan tingkat 4 dan 6 batu bata ringan masih lebih mahal.
\end{abstract}

Kata kunci: Struktur, Dinding, Bata Merah, Bata Ringan, Biaya.

Diterima Redaksi: 16-10-2020 | Selesai Revisi: 08-03-2021 | Diterbitkan Online: 09-03-2021

\section{PENDAHULUAN}

Dengan kemajuan ilmu konstruksi di Indonesia maka mendorong munculnya inovasi-inovasi pada metode pelaksanaan proyek. Inovasi-inovasi tersebut tidak dilihat hanya dalam segi kekuatan dan kestabilan struktur, namun juga harus memperhatikan segi ekonomis, praktis dan ketepatan waktu. Salah satu inovasinya adalah pemilihan jenis material dinding yang akan digunakan. Pemilihan jenis material dinding diharapkan mampu menekan biaya dan waktu pelaksanaan pekerjaan. Tetapi dalam memilih jenis material tersebut, harus juga memperhatikan kesediaan material pada daerah proyek yang dibangun dan keterampilan tenaga kerja yang dipekerjakan.

Berdasarkan Perencanaan Desain Berulang Pembangunan Rumah Susun TA 2019 tentang Material dan Spesifikasi yang dikeluarkan PUPR, material dinding menggunakan batu bata ringan dan diharapkan dari peraturan tersebut biaya proyek jika dibandingkan menggunakan batu bata merah berkurang. Dari latar belakang tersebut, penelitian ini menganalisa selisih biaya gedung menggunakan material dinding batu bata ringan jika dibandingkan dengan batu bata merah pada simulasi bangunan bertingkat di kota 
Medan, pada tingkah berapakah dinding batu bata ringan lebih murah dibandingkan dengan batu bata merah ditinjau dari analisa struktur. Studi dilakukan dengan beberapa variasi tingkat bangunan mulai dari 4 tingkat, 6 tingkat dan 8 tingkat akibat perbedaan material terhadap perencanaan dimensi struktur atas dan struktur bawah dengan melihat kekuatan, keamanan, dan efesien dimensi struktur. Pelaksanaan analisa struktur dilakukan menggunakan bantuan program komputer SAP 2000 untuk menghitung kekuatan struktur, perencanaan dimensi struktur bangunan tersebut.

\section{METODE PENELITIAN}

Gambar 1 menjelaskan diagram alir penelitian ini.

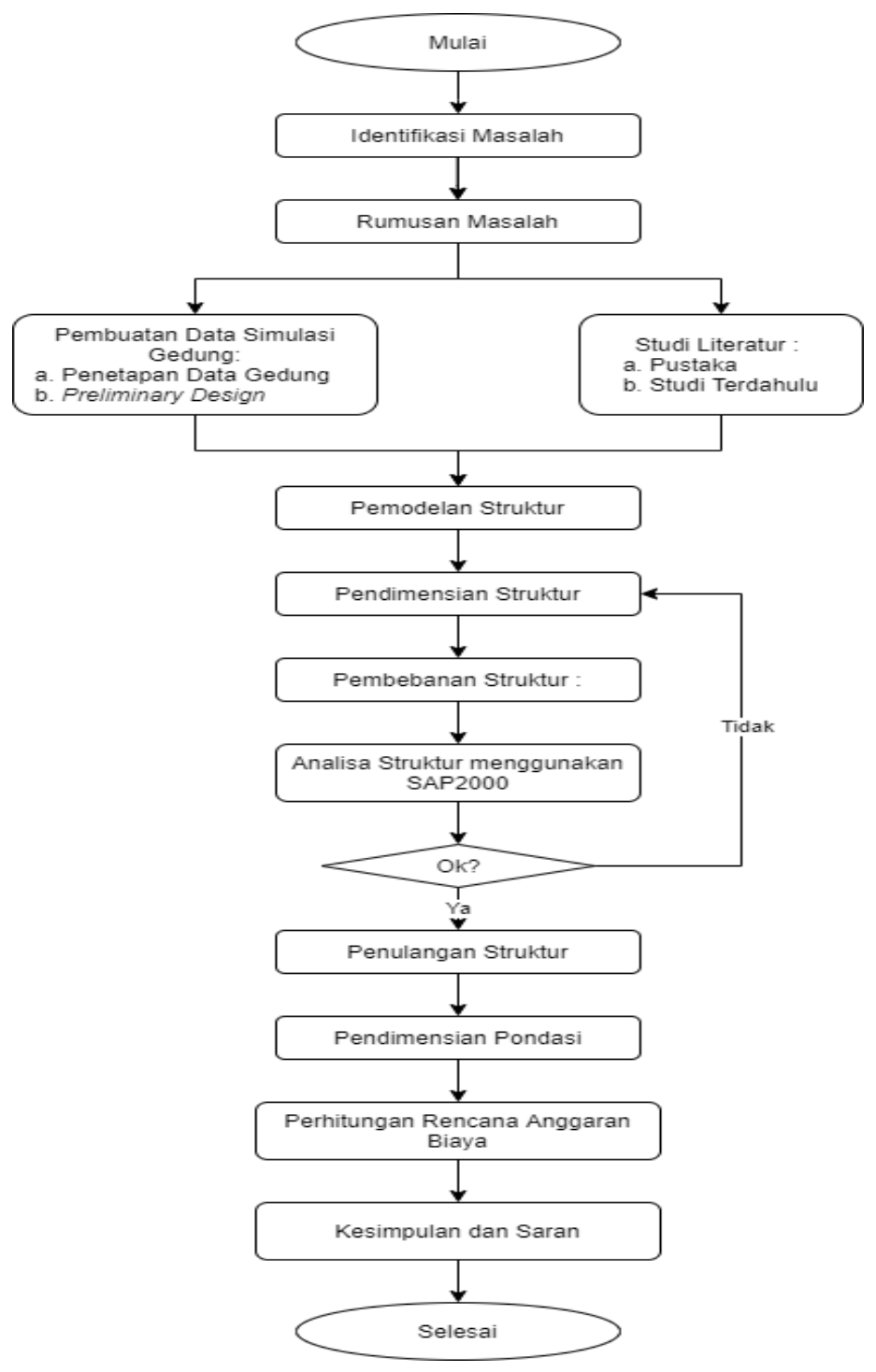

Gambar 1. Diagram alir penelitian.

Pemodelan dilakukan pada gedung yang ditetapkan mempunyai karakteristik sebagai berikut :

1. Parameter Bangunan

a. Jumlah lantai : 4, 6, 8 lantai

b. Panjang bangunan : 32 meter 

c. Lebar bangunan : 15 meter
d. Tinggi bangunan tiap lantai : 4 meter
e. Data Tanah merupakan data asumsi

2. Komponen Struktur Gedung

a. Komponen struktural beton bertulang seperti pelat, balok, kolom, dan pondasi.

- $\operatorname{Mutu}$ beton $\left(f^{\prime}\right): 29 \mathrm{MPa}$

- Mutu baja $(f y)$ tulangan longitudinal : $560 \mathrm{MPa}$

- Mutu baja $(f y)$ tulangan transversal : $390 \mathrm{MPa}$

b. Komponen non struktural

- Batu bata merah

- Ukuran : $21 \mathrm{~cm}$ x $11 \mathrm{~cm}$ x $5 \mathrm{~cm}$

- Berat Jenis : $2.000 \mathrm{~kg} / \mathrm{m}^{3}$

- Batu bata ringan

- Ukuran : $60 \mathrm{~cm}$ x $10 \mathrm{~cm}$ x $20 \mathrm{~cm}$

- Berat Jenis : $850 \mathrm{~kg} / \mathrm{m}^{3}$

\section{HASIL DAN PEMBAHASAN}

Berdasarkan hasil analisis yang sudah dilakukan, perbedaan material dinding di antara kedua simulasi gedung tersebut membuat beberapa perbedaan dimensi struktur yang dihasilkan. Ditunjukkan pada Gambar 2 - 4 dibawah ini :

a. Dimensi struktur bangunan berlantai 4

\begin{tabular}{|c|c|c|c|c|c|c|c|}
\hline \multirow{2}{*}{ Lantai } & \multirow{2}{*}{ Struktur } & \multicolumn{2}{|c|}{ Dimensi ( cm) } & \multirow{2}{*}{\begin{tabular}{c|} 
Jenis \\
Tulangan
\end{tabular}} & \multicolumn{2}{|c|}{ Jumlah Tulangan } & \multirow{2}{*}{ Sengkang } \\
\hline & & Batu Bata Merah & Batu Bata Ringan & & Tarik & Tekan & \\
\hline \multirow{2}{*}{$1-3$} & \multirow{2}{*}{ Balok } & \multirow{2}{*}{$30 \times 40$} & \multirow{2}{*}{$25 \times 40$} & Tumpuan & $2 D 18$ & 4D18 & \multirow{2}{*}{ d12-160 } \\
\hline & & & & Lapangan & 4D18 & $2 \mathrm{D} 18$ & \\
\hline \multirow{2}{*}{$1-3$} & \multirow{2}{*}{ Balok } & \multirow{2}{*}{$30 \times 55$} & \multirow{2}{*}{$30 \times 50$} & Tumpuan & $2 \mathrm{D} 18$ & $3 D 18$ & \multirow{2}{*}{ d12-240 } \\
\hline & & & & Lapangan & $3 \mathrm{D} 18$ & $2 \mathrm{D} 18$ & \\
\hline \multirow{2}{*}{$1-3$} & \multirow{2}{*}{ Balok } & \multirow{2}{*}{$40 \times 60$} & \multirow{2}{*}{$30 \times 60$} & Tumpuan & 2D21 & $3 \mathrm{D} 21$ & \multirow{2}{*}{ d12-250 } \\
\hline & & & & Lapangan & $3 \mathrm{D} 21$ & $2 \mathrm{D} 21$ & \\
\hline \multirow{2}{*}{$1-3$} & \multirow{2}{*}{ Balok } & \multirow{2}{*}{$55 \times 80$} & \multirow{2}{*}{$50 \times 70$} & Tumpuan & $3 \mathrm{D} 23$ & $3 \mathrm{D} 23$ & \multirow{2}{*}{ d12-250 } \\
\hline & & & & Lapangan & $3 \mathrm{D} 23$ & $3 \mathrm{D} 23$ & \\
\hline \multirow{2}{*}{$4-5$} & \multirow{2}{*}{ Balok } & \multirow{2}{*}{$20 \times 40$} & \multirow{2}{*}{$20 \times 35$} & Tumpuan & $2 \mathrm{D} 15$ & 3D15 & \multirow{2}{*}{ d12-170 } \\
\hline & & & & Lapangan & $3 \mathrm{D} 15$ & $2 \mathrm{D} 15$ & \\
\hline \multirow{2}{*}{$4-5$} & \multirow{2}{*}{ Balok } & \multirow{2}{*}{$25 \times 45$} & $25 \times 40$ & Tumpuan & $2 \mathrm{D} 16$ & 3D16 & d12-190 \\
\hline & & & & Lapangan & 3D16 & $2 \mathrm{D16}$ & a12-190 \\
\hline $4-5$ & Balok & $30 \times 50$ & $20 \times 35$ & Tumpuan & 2D16 & 4D16 & מב20 \\
\hline & & & $20 \times 35$ & Lapangan & 4D16 & $2 \mathrm{D} 16$ & d12-220 \\
\hline & & & & Tumpuan & 2D18 & 3D18 & \\
\hline $4-5$ & Balok & $35 \times 55$ & $35 \times 45$ & Lapangan & 3D18 & 2D18 & d12-240 \\
\hline $1-2$ & Kolom & $60 \times 60$ & $45 \times 45$ & Utama & & & d10-200 \\
\hline $3-4$ & Kolom & $35 \times 35$ & $30 \times 30$ & Utama & & & d10-200 \\
\hline $1-4$ & Plat & 12 & 12 & Utama & & & - \\
\hline Atap & Plat & 10 & 10 & Utama & & & - \\
\hline Tiang $I$ & Pancang & 500 & 400 & & & & \\
\hline
\end{tabular}

Gambar 2. Dimensi struktur bangunan berlantai 4

b. Dimensi struktur bangunan berlantai 6 


\begin{tabular}{|c|c|c|c|c|c|c|c|}
\hline \multirow{2}{*}{ Lantai } & \multirow{2}{*}{ Struktur } & \multicolumn{2}{|c|}{ Dimensi ( cm) } & \multirow{2}{*}{\begin{tabular}{|c|} 
Jenis \\
Tulangan
\end{tabular}} & \multicolumn{2}{|c|}{ Jumlah Tulangan } & \multirow{2}{*}{ Sengkang } \\
\hline & & Batu Bata Merah & Batu Bata Ringan & & Tarik & Tekan & \\
\hline \multirow{2}{*}{$1-4$} & \multirow{2}{*}{ Balok } & \multirow{2}{*}{$30 \times 40$} & \multirow{2}{*}{$25 \times 35$} & Tumpuan & $2 \mathrm{D} 22$ & 4D22 & \multirow{2}{*}{ d13-160 } \\
\hline & & & & Lapangan & $4 \mathrm{D} 22$ & $2 \mathrm{D} 22$ & \\
\hline \multirow{2}{*}{$1-4$} & \multirow{2}{*}{ Balok } & \multirow{2}{*}{$30 \times 55$} & \multirow{2}{*}{$30 \times 50$} & Tumpuan & $2 \mathrm{D} 22$ & $3 \mathrm{D} 22$ & \multirow{2}{*}{ d13-240 } \\
\hline & & & & Lapangan & $3 \mathrm{D} 22$ & $2 \mathrm{D} 22$ & \\
\hline \multirow{2}{*}{$1-4$} & \multirow{2}{*}{ Balok } & \multirow{2}{*}{$40 \times 60$} & \multirow{2}{*}{$30 \times 60$} & Tumpuan & $2 \mathrm{D} 21$ & 4D21 & \multirow{2}{*}{ d13-250 } \\
\hline & & & & Lapangan & 4D21 & 2D21 & \\
\hline \multirow{2}{*}{$1-4$} & \multirow{2}{*}{ Balok } & \multirow{2}{*}{$55 \times 80$} & \multirow{2}{*}{$50 \times 70$} & Tumpuan & $3 \mathrm{D} 23$ & 4D23 & \multirow{2}{*}{ d13-250 } \\
\hline & & & & Lapangan & $4 \mathrm{D} 23$ & $3 \mathrm{D} 23$ & \\
\hline \multirow{2}{*}{$5-7$} & \multirow{2}{*}{ Balok } & \multirow{2}{*}{$20 \times 40$} & \multirow{2}{*}{$20 \times 35$} & Tumpuan & 2D19 & 3D19 & \multirow{2}{*}{ d12-170 } \\
\hline & & & & Lapangan & 3D19 & 2D19 & \\
\hline \multirow{2}{*}{$5-7$} & \multirow{2}{*}{ Balok } & \multirow{2}{*}{$25 \times 45$} & & Tumpuan & 2D19 & $3 \mathrm{D} 19$ & \\
\hline & & & $20 \times 40$ & Lapangan & 3D19 & 2D19 & d12-190 \\
\hline $5-7$ & Balok & $30 \times 50$ & $20 \times 40$ & Tumpuan & 2D19 & 4D19 & d12-220 \\
\hline & Balok & $30 \times 50$ & $20 \times 40$ & Lapangan & 4D19 & 2D19 & $\mathrm{d} 12-220$ \\
\hline $5-7$ & Balok & $35 \times 55$ & $35 \times 45$ & Tumpuan & $2 \mathrm{D} 23$ & $3 \mathrm{D} 23$ & d12 240 \\
\hline $5-1$ & Balok & $35 \times 53$ & $35 \times 45$ & Lapangan & $3 \mathrm{D} 23$ & 2D23 & d $12-240$ \\
\hline $1-3$ & Kolom & $65 \times 65$ & $45 \times 45$ & Utama & & & d10-300 \\
\hline $4-6$ & Kolom & $40 \times 40$ & $30 \times 30$ & Utama & & & d10-250 \\
\hline $1-6$ & Plat & 12 & 12 & Utama & & & - \\
\hline Atap & Plat & 10 & 10 & Utama & & & - \\
\hline Tiang I & Pancang & 900 & 800 & & & & \\
\hline
\end{tabular}

Gambar 3. Dimensi struktur bangunan berlantai 6

c. Dimensi struktur bangunan berlantai 8

\begin{tabular}{|c|c|c|c|c|c|c|c|}
\hline \multirow{2}{*}{ Lantai } & \multirow{2}{*}{ Struktur } & \multicolumn{2}{|c|}{ Dimensi ( cm) } & \multirow{2}{*}{$\begin{array}{c}\text { Jenis } \\
\text { Tulangan }\end{array}$} & \multicolumn{2}{|c|}{ Jumlah Tulangan } & \multirow{2}{*}{ Sengkang } \\
\hline & & Batu Bata Merah & Batu Bata Ringan & & Tarik & Tekan & \\
\hline \multirow{2}{*}{$1-5$} & \multirow{2}{*}{ Balok } & \multirow{2}{*}{$30 \times 40$} & \multirow{2}{*}{$25 \times 40$} & Tumpuan & 2D19 & 3D19 & \multirow{2}{*}{ d13-160 } \\
\hline & & & & Lapangan & 3D19 & 2D19 & \\
\hline \multirow{2}{*}{$1-5$} & \multirow{2}{*}{ Balok } & \multirow{2}{*}{$30 \times 55$} & \multirow{2}{*}{$30 \times 50$} & Tumpuan & 2D19 & 4D19 & \multirow{2}{*}{ d13-240 } \\
\hline & & & & Lapangan & 4D19 & 2D19 & \\
\hline \multirow{2}{*}{$1-5$} & \multirow{2}{*}{ Balok } & \multirow{2}{*}{$40 \times 60$} & \multirow{2}{*}{$30 \times 60$} & Tumpuan & $2 \mathrm{D} 25$ & $3 \mathrm{D} 25$ & \multirow{2}{*}{ d13-250 } \\
\hline & & & & Lapangan & 3D25 & 2D25 & \\
\hline \multirow{2}{*}{$1-5$} & \multirow{2}{*}{ Balok } & \multirow{2}{*}{$55 \times 80$} & \multirow{2}{*}{$50 \times 70$} & Tumpuan & $3 \mathrm{D} 22$ & 5D22 & \multirow{2}{*}{ d13-250 } \\
\hline & & & & Lapangan & $5 \mathrm{D} 22$ & 3D22 & \\
\hline \multirow{2}{*}{$6-9$} & \multirow{2}{*}{ Balok } & \multirow{2}{*}{$20 \times 40$} & \multirow{2}{*}{$20 \times 35$} & Tumpuan & 2D19 & 3D19 & \multirow{2}{*}{ d13-150 } \\
\hline & & & & \begin{tabular}{|l} 
Lapangan \\
\end{tabular} & 3D19 & 2D19 & \\
\hline \multirow{2}{*}{$6-9$} & \multirow{2}{*}{ Balok } & \multirow{2}{*}{$25 \times 45$} & $20 \times 40$ & Tumpuan & 2D19 & 4D19 & d13-190 \\
\hline & & & $20 \times 40$ & Lapangan & 4D19 & 2D19 & d13-190 \\
\hline $6-9$ & Balok & $30 \times 50$ & $25 \times 45$ & Tumpuan & 2D19 & 4D19 & d13-210 \\
\hline (0-9 & DaIOK & $30 \times 50$ & $25 \times 45$ & Lapangan & 4D19 & 2D19 & a1s-210 \\
\hline $6-9$ & Balok & $35 \times 55$ & $35 \times 50$ & Tumpuan & 3D19 & 5D19 & d13-210 \\
\hline (0-9 & Därok & $35 \times 53$ & $53 \times 50$ & Lapangan & $5 \mathrm{D} 19$ & 3D19 & a1s-210 \\
\hline $1-4$ & Kolom & $65 \times 65$ & $50 \times 50$ & Utama & $16 \mathrm{I}$ & & d $10-250$ \\
\hline $5-8$ & Kolom & $45 \times 45$ & $40 \times 40$ & Utama & $8 \mathrm{D}$ & & d10-250 \\
\hline $1-8$ & Plat & 12 & 12 & Utama & $10 d$ & & - \\
\hline Atap & Plat & 10 & 10 & Utama & $10 d$ & & - \\
\hline Tiang & Pancang & 1100 & 800 & & & & \\
\hline
\end{tabular}

Gambar 4. Dimensi struktur bangunan berlantai 8

Ada jenis item pekerjaan struktur yang jika dihitung volumenya akan menghasilkan biaya yang sama di kedua gedung yaitu: 
1. Penulangan struktur ( antara lain : kolom, balok, pelat lantai, tangga dan pile cap )

2. Pengecoran beton struktur ( antara lain : pelat lantai, tangga dan pile cap )

Karena penelitian ini hanya membahas perbedaan harga akibat perbedaan material dinding batu bata merah dibandingkan dengan batu bata ringan, maka jenis item pekerjaan struktur yang volumenya sama tersebut tidak dihitung rencana anggaran biayanya. Selanjutnya, jenis item pekerjaan yang menghasilkan perbedaan biaya akibat perbedaan material akan dijabarkan rencana anggaran biayanya. Adapun perbandingan total biaya bangunan berlantai 4, 6 dan 8 dilihat pada Gambar 5 - 7 di bawah ini akibat perbedaan material dinding batu bata merah dibandingkan dengan batu bata ringan.

1. Rekapitulasi anggaran biaya bangunan berlantai 4

\begin{tabular}{|c|c|c|c|c|}
\hline \multirow{2}{*}{ No. } & \multirow{2}{*}{ URAIAN PEKERJAAN } & $\begin{array}{l}\text { Pengaruh Dinding Batu } \\
\text { Bata Merah }\end{array}$ & $\begin{array}{l}\text { Pengaruh Dinding Batu } \\
\text { Bata Ringan }\end{array}$ & $\begin{array}{l}\text { Selisih Biaya tiap elevasi } \\
\text { akibat perbedaan material }\end{array}$ \\
\hline & & JUMLAH HARGA (Rp) & JUMLAH HARGA (Rp) & JUMLAH HARGA（Rp) \\
\hline$\overline{1}$ & \multicolumn{2}{|c|}{ PEKERJAAN STRUKTUR DAN ARSITEKTUR } & & \\
\hline \multirow{3}{*}{1.1.} & PEKERJAAN STRUKTUR BAWAH & $965,266,791.88$ & $791,364,347.47$ & $173,902,444.41$ \\
\hline & - Pekerjaan Tiang Pancang & $781,162,962.92$ & $624,930,370.33$ & \\
\hline & - Pekerjaan Sloof & $184,103,828.96$ & $166,433,977.14$ & \\
\hline 1.2 & PEKERJAAN LANTAI & & & \\
\hline \multirow[t]{3}{*}{1.2 .1} & Pekerjaan Lantai 1 elv. $+0,00 \mathrm{~m}$ & $399,256,519.70$ & $488,626,376.65$ & $(89,369,856.95)$ \\
\hline & - Pekerjaan Struktur & $318,071,559.20$ & $221,895,634.05$ & \\
\hline & - Pekerjaan Arsitektur & $81,184,960.50$ & $266,730,742.60$ & \\
\hline \multirow[t]{3}{*}{ 1.2.2 } & Pekerjaan Lantai 2 elv. $+4,00 \mathrm{~m}$ & $675,555,524.46$ & $743,366,405.71$ & $(67,810,881.25)$ \\
\hline & - Pekerjaan Struktur & $594,370,563.96$ & $476,635,663.11$ & \\
\hline & - Pekerjaan Arsitektur & $81,184,960.50$ & $266,730,742.60$ & \\
\hline \multirow[t]{3}{*}{1.2 .3} & Pekerjaan Lantai 3 elv. $+8,00 \mathrm{~m}$ & $528,640,494.07$ & 671,787,145.00 & $(143,146,650.93)$ \\
\hline & - $\quad$ Pekerjaan Struktur & $440,246,998.10$ & $391,565,094.86$ & \\
\hline & - Pekerjaan Arsitektur & $88,393,495.97$ & $280,222,050.14$ & \\
\hline \multirow[t]{3}{*}{1.2 .4} & Pekerjaan Lantai 4 elv. $+12,00 \mathrm{~m}$ & $469,208,980.76$ & $589,033,421.55$ & $(119,824,440.79)$ \\
\hline & - Pekerjaan Struktur & $380,815,484.79$ & $308,811,371.41$ & \\
\hline & - Pekerjaan Arsitektur & $88,393,495.97$ & $280,222,050.14$ & \\
\hline \multirow[t]{2}{*}{1.2 .5} & Pekerjaan Lantai 5 elv. $+16,00 \mathrm{~m}$ & $216,867,491.45$ & $171,986,305.61$ & $44,881,185.85$ \\
\hline & - Pekerjaan Struktur & $216,867,491.45$ & $171,986,305.61$ & \\
\hline & Jumlah Total Harga Pekerjaan & $\mathbf{3 , 2 5 4 , 7 9 5 , 8 0 2 . 3 2}$ & $3,456,164,001.99$ & $(201,368,199.67)$ \\
\hline \multicolumn{4}{|c|}{$\begin{array}{c}\text { Persentase perbandingan biaya bangunan material dinding batu bata merah dibandingkan batu bata } \\
\text { ringan }\end{array}$} & $-6.187 \%$ \\
\hline
\end{tabular}

Gambar 5. Rekapitulasi anggaran biaya bangunan berlantai 4

2. Rekapitulasi anggaran biaya bangunan berlantai 6

\begin{tabular}{|c|c|c|c|c|}
\hline \multirow{2}{*}{ NO. } & \multirow{2}{*}{ URAIAN PEKERJAAN } & $\begin{array}{l}\text { Pengaruh Dinding Batu } \\
\text { Bata Merah }\end{array}$ & $\begin{array}{l}\text { Pengaruh Dinding Batu } \\
\text { Bata Ringan }\end{array}$ & $\begin{array}{l}\text { Selisih Biaya tiap elevasi } \\
\text { akibat perbedaan material }\end{array}$ \\
\hline & & JUMLAH HARGA (Rp) & JUMLAH HARGA (Rp) & JUMLAH HARGA (Rp) \\
\hline 1 & \multicolumn{2}{|c|}{ PEKERJAAN STRUKTUR DAN ARSITEKTUR } & & \\
\hline \multirow[t]{3}{*}{ 1.1. } & PEKERJAAN STRUKTUR BAWAH & $\begin{array}{r}1,586,988,020.29 \\
\end{array}$ & $1,260,062,125.22$ & $326,925,895.07$ \\
\hline & - Pekerjaan Tiang Pancang & $1,406,093,333.25$ & $1,093,628,148.08$ & \\
\hline & - Pekerjaan Sloof & $180,894,687.04$ & $166,433,977.14$ & \\
\hline 1.2 & PEKERJAAN LANTAI & & & \\
\hline \multirow[t]{3}{*}{ 1.2.1 } & Pekerjaan Lantai 1 elv. $+\mathbf{0 , 0 0} \mathrm{m}$ & $\mathbf{4 3 2 , 3 4 1 , 3 1 1 . 4 1}$ & $488,626,376.65$ & $(56,285,065.24)$ \\
\hline & - Pekerjaan Struktur & $352,598,058.00$ & $221,895,634.05$ & \\
\hline & - Pekerjaan Arsitektur & $79,743,253.41$ & $266,730,742.60$ & \\
\hline \multirow[t]{3}{*}{ 1.2.2 } & Pekerjaan Lantai 2 elv. $+\mathbf{4 , 0 0} \mathrm{m}$ & 703,837,647.09 & $\mathbf{7 4 3 , 3 6 6 , 4 0 5 . 7 1}$ & $(39,528,758.62)$ \\
\hline & - Pekerjaan Struktur & $624,094,393.68$ & $476,635,663.11$ & \\
\hline & - Pekerjaan Arsitektur & $79,743,253.41$ & $266,730,742.60$ & \\
\hline \multirow[t]{3}{*}{1.2 .3} & Pekerjaan Lantai 3 elv. $+8,00 \mathrm{~m}$ & 703,837,647.09 & $743,366,405.71$ & $(39,528,758.62)$ \\
\hline & - Pekerjaan Struktur & $624,094,393.68$ & $476,635,663.11$ & \\
\hline & - Pekerjaan Arsitektur & $79,743,253.41$ & $266,730,742.60$ & \\
\hline \multirow[t]{3}{*}{ 1.2.4 } & Pekerjaan Lantai 4 elv. $+12,00 \mathrm{~m}$ & $550,752,973.98$ & $671,787,145.00$ & $(121,034,171.03)$ \\
\hline & - Pekerjaan Struktur & $463,801,185.10$ & $391,565,094.86$ & \\
\hline & - Pekerjaan Arsitektur & $86,951,788.88$ & $280,222,050.14$ & \\
\hline \multirow[t]{3}{*}{1.2 .5} & Pekerjaan Lantai 5 elv. $+\mathbf{1 6 , 0 0}$ m & $492,697,229.43$ & $604,784,489.43$ & $(112,087,260.01)$ \\
\hline & - Pekerjaan Struktur & $405,745,440.55$ & $324,562,439.29$ & \\
\hline & - Pekerjaan Arsitektur & $86,951,788.88$ & $280,222,050.14$ & \\
\hline \multirow[t]{3}{*}{1.2 .6} & Pekerjaan Lantai 6 elv. $+20,00 \mathrm{~m}$ & $492,697,229.43$ & $604,784,489.43$ & $(112,087,260.01)$ \\
\hline & - Pekerjaan Struktur & $405,745,440.55$ & $324,562,439.29$ & \\
\hline & - Pekerjaan Arsitektur & $86,951,788.88$ & $280,222,050.14$ & \\
\hline \multirow[t]{3}{*}{ 1.2.7 } & Pekerjaan Lantai 7 elv. $+\mathbf{2 4 , 0 0 ~ m ~}$ & $213,440,591.13$ & $\mathbf{1 8 7 , 7 3 7 , 3 7 3 . 4 9}$ & $25,703,217.64$ \\
\hline & - Pekerjaan Struktur & $213,440,591.13$ & $187,737,373.49$ & \\
\hline & Jumlah Total Harga Pekerjaan & $5,176,592,649.84$ & $5,304,514,810.65$ & $(127,922,160.81)$ \\
\hline \multicolumn{4}{|c|}{$\begin{array}{l}\text { Persentase perbandingan biaya bangunan material dinding batu bata merah dibandingkan batu bata } \\
\text { ringan }\end{array}$} & $-2.471 \%$ \\
\hline
\end{tabular}

Gambar 6. Rekapitulasi anggaran biaya bangunan berlantai 6 
3. Rekapitulasi anggaran biaya bangunan berlantai 8

\begin{tabular}{|c|c|c|c|c|}
\hline \multirow{2}{*}{ NO. } & \multirow{2}{*}{ URAIAN PEKERJAAN } & $\begin{array}{c}\text { Pengaruh Dinding Batu } \\
\text { Bata Merah }\end{array}$ & $\begin{array}{c}\text { Pengaruh Dinding Batu } \\
\text { Bata Ringan }\end{array}$ & $\begin{array}{c}\text { Selisih Biaya tiap elevasi } \\
\text { akibat perbedaan material }\end{array}$ \\
\hline & & JUMLAH HARGA (Rp) & JUMLAH HARGA (Rp) & JUMLAH HARGA（Rp) \\
\hline 1 & \multicolumn{2}{|c|}{ PEKERJAAN STRUKTUR DAN ARSITEKTUR } & & \\
\hline 1.1. & PEKERJAAN STRUKTUR BAWAH & $2,055,685,798.04$ & $1,259,271,995.23$ & $796,413,802.81$ \\
\hline & - Pekerjaan Tiang Pancang & $1,874,791,111.00$ & $1,093,628,148.08$ & \\
\hline & - Pekerjaan Sloof & $180,894,687.04$ & $165,643,847.15$ & \\
\hline 1.2 & PEKERJAAN LANTAI & & & \\
\hline \multirow[t]{3}{*}{ 1.2.1 } & Pekerjaan Lantai 1 elv. $+0,00 \mathrm{~m}$ & $\mathbf{4 3 2 , 3 4 1 , 3 1 1 . 4 1}$ & $\mathbf{5 1 4 , 9 5 3 , 9 8 7 . 3 1}$ & $(82,612,675.90)$ \\
\hline & - Pekerjaan Struktur & $352,598,058.00$ & $252,720,347.22$ & \\
\hline & - Pekerjaan Arsitektur & $79,743,253.41$ & $262,233,640.09$ & \\
\hline \multirow{3}{*}{ 1.2.2 } & Pekerjaan Lantai 2 elv. $\mathbf{+ 4 , 0 0 ~} \mathrm{m}$ & $703,837,647.09$ & $768,527,244.20$ & $(64,689,597.12)$ \\
\hline & - Pekerjaan Struktur & $624,094,393.68$ & $506,293,604.12$ & \\
\hline & - Pekerjaan Arsitektur & $79,743,253.41$ & $262,233,640.09$ & \\
\hline \multirow{3}{*}{1.2 .3} & Pekerjaan Lantai 3 elv. $+8,00 \mathrm{~m}$ & $703,837,647.09$ & $768,527,244.20$ & $(64,689,597.12)$ \\
\hline & - Pekerjaan Struktur & $624,094,393.68$ & $506,293,604.12$ & \\
\hline & - Pekerjaan Arsitektur & $79,743,253.41$ & $262,233,640.09$ & \\
\hline \multirow{3}{*}{$\mathbf{1 . 2 . 4}$} & Pekerjaan Lantai 4 elv. $+12,00$ m & $703,837,647.09$ & $768,527,244.20$ & $(64,689,597.12)$ \\
\hline & - Pekerjaan Struktur & $624,094,393.68$ & $506,293,604.12$ & \\
\hline & - Pekerjaan Arsitektur & $79,743,253.41$ & $262,233,640.09$ & \\
\hline \multirow{3}{*}{ 1.2.5 } & Pekerjaan Lantai 5 elv. $+\mathbf{1 6 , 0 0} \mathrm{m}$ & $578,902,051.51$ & $717,105,951.43$ & $(138,203,899.92)$ \\
\hline & - Pekerjaan Struktur & $493,391,969.73$ & $445,878,106.32$ & \\
\hline & - Pekerjaan Arsitektur & $85,510,081.78$ & $271,227,845.12$ & \\
\hline \multirow{3}{*}{ 1.2.6 } & Pekerjaan Lantai 6 elv. $+\mathbf{2 0 , 0 0} \mathrm{m}$ & $517,419,406.64$ & $645,327,318.56$ & $(127,907,911.92)$ \\
\hline & - Pekerjaan Struktur & $431,909,324.86$ & $374,099,473.45$ & \\
\hline & - Pekerjaan Arsitektur & $85,510,081.78$ & $271,227,845.12$ & \\
\hline \multirow[t]{3}{*}{ 1.2.7 } & Pekerjaan Lantai 7 elv. $+\mathbf{2 4 , 0 0} \mathrm{m}$ & $517,419,406.64$ & $645,327,318.56$ & $(127,907,911.92)$ \\
\hline & - Pekerjaan Struktur & $431,909,324.86$ & $374,099,473.45$ & \\
\hline & - Pekerjaan Arsitektur & $85,510,081.78$ & $271,227,845.12$ & \\
\hline \multirow[t]{3}{*}{$\mathbf{1 . 2 . 8}$} & Pekerjaan Lantai 8 elv. $+28,00 \mathrm{~m}$ & $517,419,406.64$ & $645,327,318.56$ & $(127,907,911.92)$ \\
\hline & - Pekerjaan Struktur & $431,909,324.86$ & $374,099,473.45$ & \\
\hline & - Pekerjaan Arsitektur & $85,510,081.78$ & $271,227,845.12$ & \\
\hline 1.2.9 & Pekerjaan Lantai 9 elv. $+32,00 \mathrm{~m}$ & $210,013,690.81$ & 181,794,624.03 & $28,219,066.78$ \\
\hline & - Pekerjaan Struktur & $210,013,690.81$ & $181,794,624.03$ & \\
\hline & Jumlah Total Harga Pekerjaan & $6,940,714,012.96$ & $6,914,690,246.30$ & $26,023,766.66$ \\
\hline & " & nding batu bata mer: & dingkan batu bata & $0.375 \%$ \\
\hline
\end{tabular}

Gambar 7. Rekapitulasi anggaran biaya bangunan berlantai 8 .

\section{SIMPULAN}

Dapat disimpulkan bahwa selisih biaya pada simulasi bangunan menggunakan material dinding : Batu bata ringan lebih mahal dibandingkan dengan batu bata merah, terdapat selisih biaya $\mathrm{Rp}$ 201.368.199 atau 6,187\%, untuk tingkat 4 dan terdapat selisih biaya $\mathrm{Rp} 127.922 .160$ atau 2,471\% untuk tingkat 6 , sedangkan untuk tingkat 8 batu bata ringan lebih murah dibandingkan dengan batu bata merah, terdapat selisih biaya Rp 26.023.766 atau 0,375\%. Dinding batu bata ringan lebih murah dibandingkan dengan batu bata merah mulai tingkat 8 , sedangkan tingkat 4 dan 6 batu bata ringan masih lebih mahal.

\section{DAFTAR PUSTAKA}

Asroni, Ali. 2010. Balok Dan Pelat Beton Bertulang. Penerbit Graha

Ilmu, Yogyakarta.

BSN, 2012, SNI 1726-2012: Tata Cara Perencanaan Ketahanan Gempa Untuk Struktur Bangunan Gedung dan Non Gedung, Badan Standardisasi

Nasional, Jakarta.

Departemen Pekerjaan Umum, 1987, Pedoman Perencanaan Pembebanan Indonesia Untuk Rumah Dan Gedung (PPPURG 1987), Yayasan Badan 
Pekerjaan Umum, Jakarta.

Dewan Standardisasi Nasional. (1991). SNI 15-2094-1991; Mutu dan Cara Uji Bata Merah , P\&I, Jakarta.

Dipohusodo, Istimawan. 1996. Struktur Beton Bertulang. Gramedia Pustaka Utama. Jakarta.

Kementrian Pekerjaan Umum Perumahan Rakyat, 2016, Permen PUPR

No.28/PRT/M/2016, Tentang Pedoman Analisis Harga satuan Pekerjaan

Bidang Pekerjaan Umum.

Nugraha, Paulus, dkk. 1985. Manajemen Proyek Konstruksi 1. Kartika Yudha. Surabaya

Standar Nasional Indonesia. 2013. Beban Minimum untuk Perencanaan Bangunan Gedung dan Struktur Lain, SNI - 1727 - 2013. Badan Standarisasi Nasional.

Standar Nasional Indonesia, 2013. Persyaratan Beton Struktural untuk Bangunan Gedung, SNI - 2847 - 2013. Badan Standarisasi Nasional, Bandung 